\title{
Blood Bag Shaker Dilengkapi Pemilihan Kecepatan Motor
}

\author{
Meilia Safitri*1, Widya Dwi Iswara², Tri Harjono ${ }^{3}$ \\ Universitas Muhammadiyah Yogyakarta, Indonesia
}

INFO ARTIKEL

Alamat Web Artikel:

https://journal.umy.ac.id/index.php/mt /article/view/8632

DOI:

https://doi.org/10.18196/mt.010208

Data Artikel:

Diterima:

04 April 2020

Direview:

15 April 2020

Direvisi :

21 April 2020

Disetujui :

30 April 2020

Korespondensi: $(\mathbf{8}$ pt $)$

meilia.safitri@vokasi.umy.ac.id

\begin{abstract}
ABSTRAK
Blood Bag Shaker merupakan alat yang berfungsi untuk menimbang darah yang masuk ke kantong dan menggoyangkan kantong darah secara otomatis pada kegiatan donor darah. Menggoyangkan kantong darah berfungsi untuk mencampurkan antara darah dan antikoagulan agar tidak terjadi penggumpalan pada darah. Pada penelitian ini dirancang suatu alat yang bertujuan untuk memudahkan proses pekerjaan petugas PMI dalam menggoyangkan kantong darah sehingga waktu yang digunakan lebih efektif dan efisien. Alat yang dirancang pada penelitian ini dikendalikan oleh mikrokontroler ATMega 328 dengan memanfaatkan sensor load cell untuk menimbang jumlah darah yang masuk ke kantong yang nilainya dikonversikan menjadi satuan mililiter. Motor servo digunakan untuk menggoyangkan kantong darah yang diletakkan pada alat dan pada alat ini terdapat pemilihan kecepatan motor. Pada hasil penelitian ini dilakukan beberapa pengukuran salah satunya untuk hasil pengukuran tegangan pada motor didapatkan rata-rata sebesar 4,86 Volt. Untuk hasil pengukuran berat didapatkan persentase error terkecil pada pengukuran sampel menggunakan kecap sebesar $0,23 \%$ pada berat $100 \mathrm{ml}$, sedangkan untuk persentase error terbesar menggunakan sampel kecap didapatkan sebesar 3,08\% pada berat $50 \mathrm{ml}$. Hasil rata-rata error pada pengukuran berat menggunakan sampel kecap sebesar $1,76 \%$.
\end{abstract}

Kata Kunci: ATMega 328, Load Cell, Motor Servo

\section{PENDAHULUAN}

Darah memiliki banyak peranan penting bagi tubuh, seperti sebagai sarana untuk transportasi nutrisi tubuh, untuk pertahanan tubuh terhadap partikel-partikel asing, serta sebagai pertahanan lingkungan dalam tubuh agar terjaga konstan. Akibat dari kekurangan jumlah darah dapat menyebabkan kerusakan jaringan serta terjadi pada organ-organ vital yang tidak berjalan sesuai fungsinya, sehingga mengakibatkan kematian. Berkaitan dengan kekurangan jumlah darah dalam tubuh, hal ini dapat diatasi dengan menambahkan volume darah dari luar yang berasal dari darah pendonor.

Darah yang akan ditransfusikan harus dalam kondisi yang baik, maka darah akan disimpan ditempat tertentu. Sebelum penyimpanan darah, pada kegiatan donor darah dilakukan beberapa tahap [1][2], salah satu tahap yang dilakukan adalah menimbang dan menggoyangkan kantong darah [3]. Menggoyangkan kantong darah bertujuan untuk mencampurkan antara komponen darah dan zat antikoagulan [4] yang ada di dalam kantong tersebut [5][6].

Dalam proses ini ada beberapa petugas Palang Merah Indonesia (PMI) masih melakukannya secara manual. Proses manual dapat mempengaruhi pencampuran yang tidak merata antara darah dan antikoagulan serta membutuhkan petugas PMI untuk menggoyangkan kantong darah selama proses pengambilan darah berlangsung sehingga membuat pekerjaan petugas PMI kurang efektif [7].

Pada penelitian yang dilakukan oleh Santi Lailatus Solihach dengan judul Alat Automatic Blood Bag Shaker menggunakan mikrokontroler ATMega16, sensor load cell, serta terdapat tiga pemilihan volume kantung darah, yaitu $250 \mathrm{ml}, 350 \mathrm{ml}$, dan $450 \mathrm{ml}$ [8][9]. Namun pada alat ini belum terdapat pemilihan kecepatan motor [10][11], dan pada hasil pengukuran output tegangan 
pada rangkaian penguat sensor load cell belum stabil [12]. Hal ini mempengaruhi ketidaksesuaian hasil pada volume darah yang akan masuk, yang akan ditampilkan pada LCD [13][14].

Sehingga pada penelitian ini dirancang Blood Bag Shaker yang dilengkapi pemilihan kecepatan yang bisa membantu para petugas PMI dalam hal menimbang darah yang masuk ke kantong serta mencampurkan antikoagulan dan darah dengan sempurna secara otomatis yang dilengkapi pemilihan kecepatan motor. Pemiliha kecepatan ini digunakan untuk mengantisipasi ukuran kantong darah mempunyai jumlah antikoagulan yang berbeda-beda. Dengan adanya pemilihan kecepatan proses pencampuran untuk masing-masing ukuran kantong dapat dicapai pencampuran darah dengan koagulan yang lebih sempurna.

\section{METODE PENELITIAN}

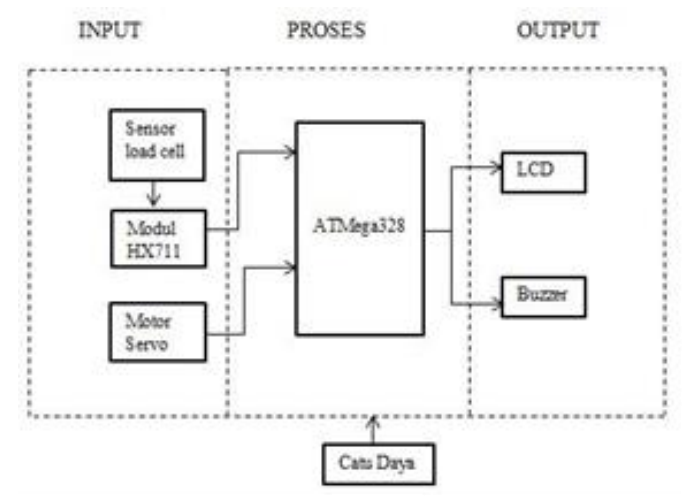

Gambar 1. Blok Diagram Alat

Saat sistem dihidupkan, maka seluruh rangkaian mendapatkan supply tegangan dari catu daya atau power supply. Motor servo digunakan sebagai penggerak dari tempat kantong darah, yang dihubungkan ke mikrokontroler ATMega 328. Sensor load cell akan mendeteksi berat yang masuk ke kantong, karena output dari sensor ini kecil dibutuhkan rangkaian penguat sehingga digunakan modul HX711 sebagai rangkaian penguat. Berat darah yang masuk ke kantong akan dikonversikan oleh modul ini yang datanya akan dikelola oleh mikrokontroler ATMega 328, lalu nilai berat akan ditampilkan pada LCD $16 \times 2$. Ketika berat telah mencapai ukuran kantong yang telah ditentukan maka buzzer akan bunyi.

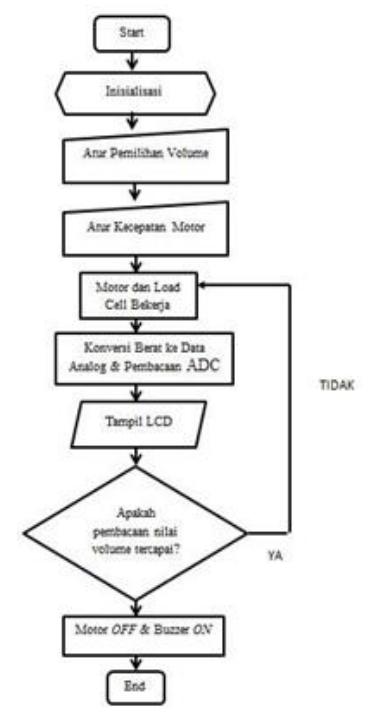

Gambar 2. Diagram Alir

Medika Teknika : Jurnal Teknik Elektromedik Indonesia, Vol 01 No. 2, April $2020 \mid 45$ 
Saat alat dihidupkan terjadi proses inisialisasi bertujuan untuk menjalankan perintah-perintah yang telah diberikan. Lalu mengatur pemilihan ukuran volume kantong yang dibutuhkan yaitu 250 $\mathrm{ml}, 350 \mathrm{ml}$ dan $450 \mathrm{ml}$. Kemudian mengatur pemilihan kecepatan yaitu lambat, sedang dan cepat. Ketika ditekan tombol start, motor akan bekerja dan sensor load cell akan mendeteksi berat yang masuk ke kantong. Nilai berat akan dikonversi oleh mikrokontroler yang mengolah data analog menjadi digital, yag hasilnya ditampilkan pada LCD 16x2. Apabila pembacaan nilai untuk ukuran volume telah tercapai maka motor akan berhenti dan buzzer bunyi menandakan proses telah selesai.

Rangkaian ini menggunakan power supply dengan tegangan sebesar $5 \mathrm{~V}$. Lalu terdapat rangkaian minimum sistem yang menggunakan ATMega 328 dan menggunakan LCD 16x2 untuk menampilkan hasil pada alat. Terdapat sensor load cell sebesar $1 \mathrm{~kg}$ yang dihubungkan ke modul HX711. Kemudian terdapat motor servo serta apabila alat telah selesai dalam menjalankan prosesnya maka ada pemberitahuan yaitu dirancang rangkaian buzzer. Pada perancangan perangkat keras untuk skematik rangkaian secara keseluruhan dapat dilihat pada Gambar 3 dibawah ini:

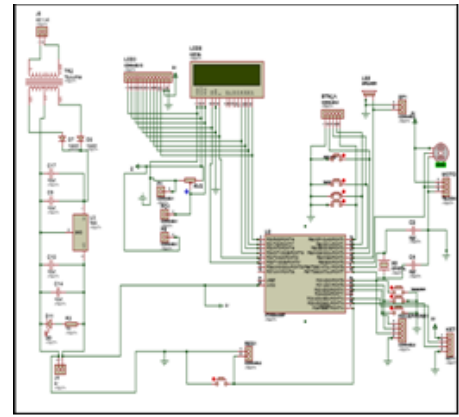

Gambar 3. Rangkaian Keseluruhan

Catu daya merupakan rangkaian yang berperan sebagai pemberi sumber daya untuk rangkaian-rangkaian yang lainnya, dengan memberikan tegangan AC $220 \mathrm{~V}$. Pada rangkaian ini tegangan AC akan diubah menjadi tegangan DC yang sebelumnya telah disearahkan oleh dioda. Sehingga tegangan DC inilah untuk dibagikan ke rangkaian-rangkaian yang lain. Kemudian pada saat melewati IC Regulator 7805 maka tegangan akan diturunkan sehingga mendapatkan keluaran sebesar $5 \mathrm{~V}$.

Rangkaian minimum sistem ini berfungsi sebagai pengendali dengan menggunakan ATMega 328. Tegangan yang dibutuhkan agar IC ini bekerja adalah sebesar 5 volt. Pada rangkaian dihubungkan ke LCD 16x2, untuk menampilkan data yang akan diolah oleh ADC menjadi nilai dalam bentuk mililiter. LCD dapat dihidupkan dengan memberikan tegangan sebesar $5 \mathrm{~V}$ yang dihubungkan pada pin VDD dan ground dihubungkan pada pin VSS. Kemudian pada rangkaian ini juga terdapat resistor variabel dengan nilai sebesar 2,2K Ohm yang digunakan untuk mengatur tingkat kecerahan pada LCD 16x2. Rangkaian Minimum Sistem dan LCD dapat dilihat pada Gambar 4 seperti dibawah ini:

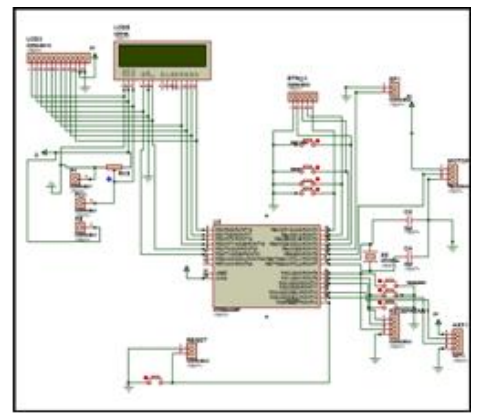

Gambar 4. Rangkaian Minimum Sistem dan LCD 16x2

Medika Teknika : Jurnal Teknik Elektromedik Indonesia, Vol 01 No. 2, April 2020| 46 


\section{Safitri, Iswara, Harjono}

Blood Bag Shaker Dilengkapi Pemilihan Kecepatan Motor

Pada perancangan rangkaian sensor berat menggunakan sensor load cell dan modul penguat X711 untuk proses menimbang dalam melakukan pengambilan data. Agar sensor ini dapat bekerja maka modul pada HX711 membutuhkan tegangan sebesar 5V dihubungkan pada VCC dan ground, PORTC pin 12 (pin 4 analog) Arduino dihubungkan pada SCX, dan PORTC pin 13 (pin 5 analog) dihubungkan ke DT. Rangkaian sensor berat dapat dilihat pada Gambar 5 sebagai berikut:

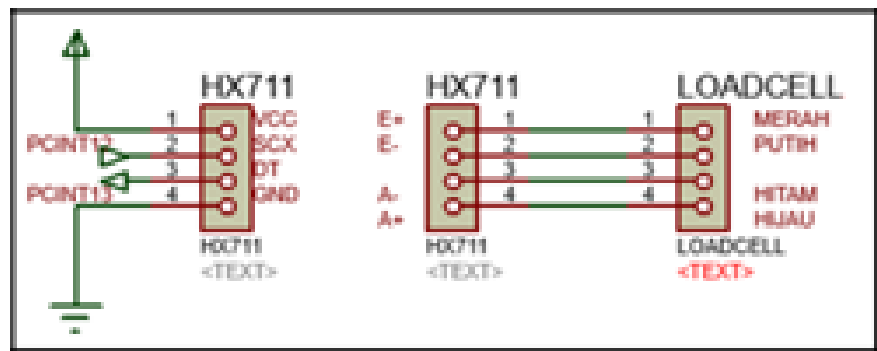

Gambar 5. Rangkaian Sensor Berat

Pada rangkaian ini digunakan untuk menggerakkan alat ketika dalam proses pengukuran data. Motor yang digunakan pada rangkaian ini adalah salah satu jenis motor DC berupa motor servo tipe MG945R. Motor ini terdiri dari tiga kabel, kabel pertama sebagai input dihubungkan dengan tegangan sebesar 5V, kabel kedua dihubungkan ke pin mikrokontroler pada Port B pin 5, dan kabel ketiga dihubungkan pada ground. Rangkaian motor servo dapat dilihat pada Gambar 6 sebagai berikut:

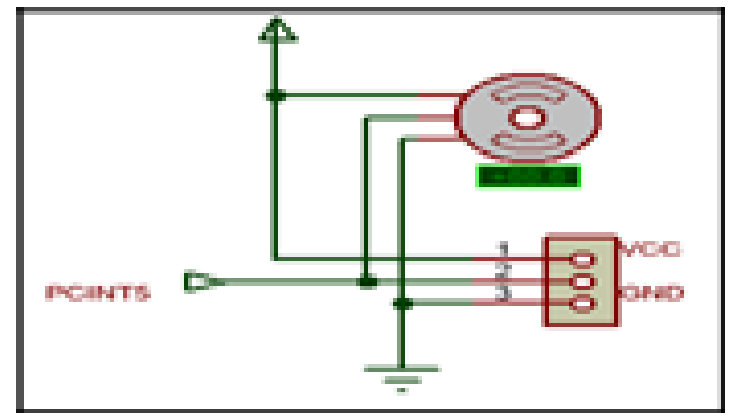

Gambar 6. Rangkaian Motor Servo

Pada rangkaian buzzer ini digunakan sebagai pemberitahuan bahwa proses kerja alat telah selesai. Salah satu inputnya dihubungkan ke pin mikrokontroler pada Port $\mathrm{C}$ pin 4 dan ke ground. Sehingga output yang dihasilkan berupa bunyi atau suara. Rangkaian buzzer dapat dilihat pada Gambar 7 sebagai berikut:

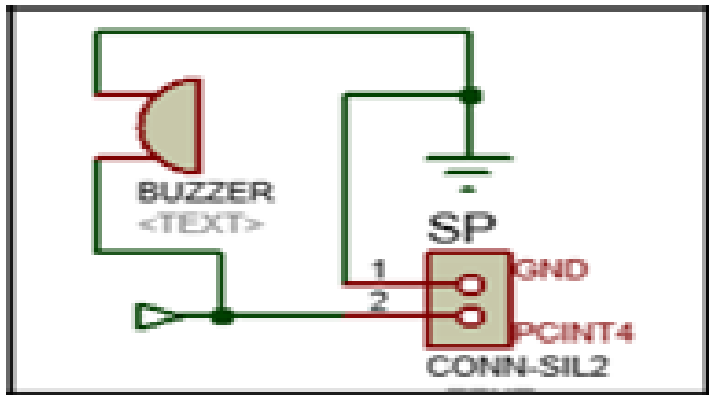

Gambar 7. Rangkaian Buzzer

Medika Teknika : Jurnal Teknik Elektromedik Indonesia, Vol 01 No. 2, April $2020 \mid 47$ 


\section{Safitri, Iswara, Harjono}

Blood Bag Shaker Dilengkapi Pemilihan Kecepatan Motor

\section{HASIL DAN PEMBAHASAN}

Pada Tabel 1 berikut adalah tabel hasil pengukuran motor servo:

Tabel 1. Hasil Pengukuran Motor Servo

\begin{tabular}{|c|c|c|c|}
\hline No. & Pengaturan Kecepatan & Kondisi Motor & Rata-rata Tegangan (V) \\
\hline \multirow{2}{*}{1} & \multirow{2}{*}{ Lambat } & Mati & 0 \\
\cline { 3 - 4 } & \multirow{2}{*}{2} & Hidup & 4,86 \\
\hline \multirow{2}{*}{3} & Sedang & Mati & 0 \\
\cline { 2 - 4 } & \multirow{2}{*}{ Cepat } & Hidup & 4,86 \\
\cline { 2 - 4 } & & Mati & 0 \\
\hline
\end{tabular}

Berdasarkan Tabel 1. terlihat bahwa, rata-rata tegangan pada saat motor menyala ada di kisaran 4,86 volt.

Berikut adalah hasil dari pengukuran menggunakan anak timbangan ditunjukkan pada Tabel 2. Tabel 2. Hasil Pengukuran Terhadap Anak Timbangan

\begin{tabular}{|c|c|c|c|c|c|c|c|}
\hline \multirow{2}{*}{$\begin{array}{c}\text { Anak } \\
\text { Timbangan } \\
\text { (gram) }\end{array}$} & \multicolumn{5}{|c|}{ Hasil Pengukuran ke- } & \multirow{2}{*}{$\begin{array}{c}\text { Rata-rata } \\
\text { (gram) }\end{array}$} & \multirow{2}{*}{$\begin{array}{c}\text { Pembacaan Erro } \\
(\%)\end{array}$} \\
\hline & 1 & 2 & 3 & 4 & 5 & & \\
\hline 0 & 0 & 0 & 0 & 0 & 0 & 0 & 0 \\
\hline 50 & 49,73 & 50,08 & 49,95 & 49,67 & 49,79 & 49,844 & 0,31 \\
\hline 100 & 97,37 & 97,39 & 97,53 & 97,36 & 97,24 & 97,378 & 2,62 \\
\hline 150 & 146,09 & 145,87 & 146,09 & 145,97 & 146,06 & 146,01 & 2,65 \\
\hline 200 & 194,43 & 194,34 & 194,12 & 194,18 & 194,38 & 194,29 & 2,85 \\
\hline 250 & 242,82 & 242,75 & 242,42 & 242,57 & 242,53 & 242,61 & 2,95 \\
\hline 300 & 291,31 & 291,22 & 290,98 & 290,8 & 291,23 & 291,1 & 2,96 \\
\hline 350 & 339,1 & 339 & 338,8 & 338,92 & 338,91 & 338,94 & 3,15 \\
\hline 400 & 387,06 & 387,04 & 387,27 & 387,06 & 386,92 & 387,07 & 3,23 \\
\hline 450 & 436,46 & 436,39 & 436,33 & 436,41 & 436,4 & 436,39 & 3,02 \\
\hline \multicolumn{7}{|c|}{ Rata-rata Persentase Error } & 2,37 \\
\hline \multicolumn{7}{|c|}{ Rata-rata Nilai Koreksi } & 6,63 \\
\hline
\end{tabular}

Tabel 2 menunjukkan bahwa pembacaan berat yang ditunjukkan oleh alat yang dirancang menghasilkan pembacaan dengan akurasi mencapai $97 \%$.

Berikut adalah hasil dari pengukuran menggunakan kecap ditunjukkan pada Tabel 3. Pemilihan kecap sebagai bahan uji dilatarbelakangi oleh kecap memiliki massa jenis yang hampir sama dengan darah.

Medika Teknika : Jurnal Teknik Elektromedik Indonesia, Vol 01 No. 2, April 2020| 48 
Safitri, Iswara, Harjono

Blood Bag Shaker Dilengkapi Pemilihan Kecepatan Motor

Tabel 3. Hasil Pengukuran Menggunakan Kecap

\begin{tabular}{|c|c|c|c|c|c|c|c|}
\hline \multirow{2}{*}{$\begin{array}{c}\text { Timbangan } \\
\text { Pembanding (gr) }\end{array}$} & \multicolumn{5}{|c|}{ Hasil Pengukuran ke- } & \multirow{2}{*}{ Rata-rata (ml) } & \multirow{2}{*}{$\begin{array}{c}\text { Pembacaan } \\
\text { Error }(\%)\end{array}$} \\
\hline & 1 & 2 & 3 & 4 & 5 & & \\
\hline 0 & 0 & 0 & 0 & 0 & 0 & 0 & 0 \\
\hline 50 & 51,35 & 51,67 & 51,59 & 51,59 & 51,51 & 51,54 & 3,08 \\
\hline 100 & 100,16 & 100,21 & 100,29 & 100,3 & 100,2 & 100,23 & 0,23 \\
\hline 150 & 147,73 & 147,76 & 148,6 & 148,44 & 148,53 & 148,21 & 1,19 \\
\hline 200 & 198,12 & 198,02 & 198,01 & 197,74 & 197,56 & 197,89 & 1,05 \\
\hline 250 & 245,07 & 245,12 & 244,68 & 244,99 & 244,98 & 244,96 & 2,01 \\
\hline 300 & 292,56 & 292,66 & 292,91 & 292,66 & 292,68 & 292,69 & 2,43 \\
\hline 350 & 341,8 & 342,22 & 342,21 & 342,17 & 342,36 & 342,15 & 2,24 \\
\hline 400 & 390,67 & 390,53 & 390,43 & 390,93 & 390,62 & 390,63 & 2,34 \\
\hline 450 & 436,33 & 436,63 & 435,95 & 436,08 & 436,38 & 436,27 & 3,05 \\
\hline \multicolumn{7}{|c|}{ Rata-rata Persentase Error } & 1,76 \\
\hline \multicolumn{7}{|c|}{ Rata-rata Nilai Koreksi } & 4,54 \\
\hline
\end{tabular}

Berikut adalah hasil dari pengukuran menggunakan air dan sirup yang ditunjukkan pada Tabel 4. Pengujian ini bertujuan untuk melihat seberapa efektif alat yang dirancang dalam mencapurkan darah dengan koagulan. Penggunaan air dan sirup digunakan untuk mensimulasikan darah dan koagulan. Hal ini untuk memudahkan pengamatan dalam proses pencampuran.

Tabel 4. Hasil Pencampuran Air dengan Sirup

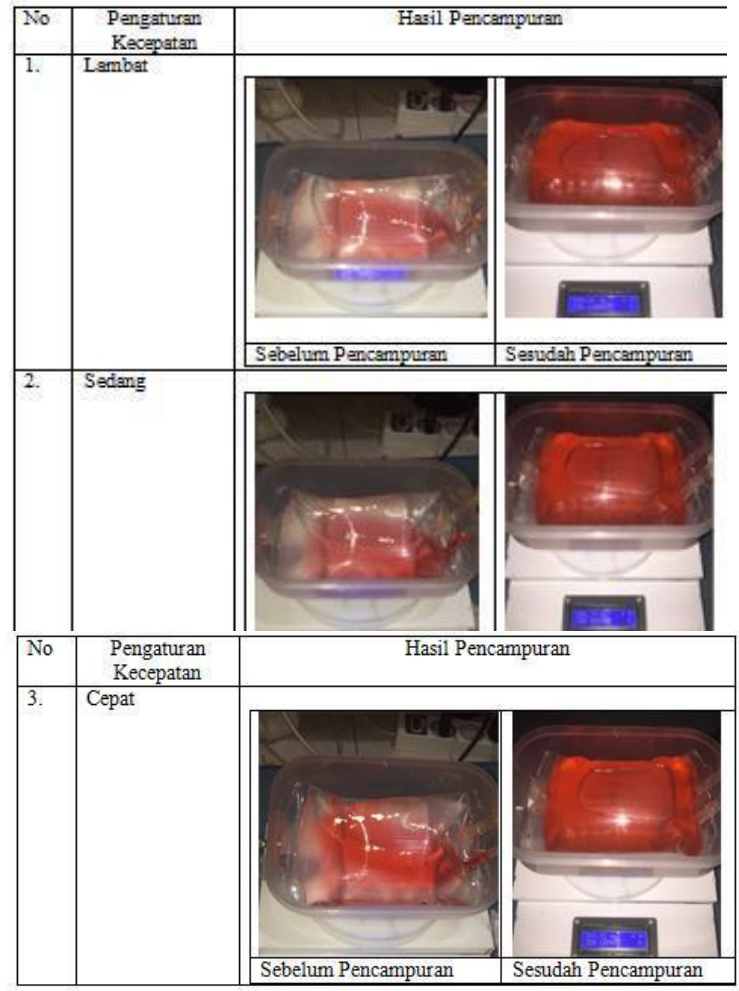

Medika Teknika : Jurnal Teknik Elektromedik Indonesia, Vol 01 No. 2, April 2020 | 49 
Pada pengujian motor servo diperoleh rata-rata nilai tegangannya 4,86 Volt untuk pengaturan kecepatan lambat dan sedang. Untuk pengaturan kecepatan cepat sebesar 4,85 Volt. Untuk pengujian menggunakan anak timbangan diperoleh hasil nilai rata-rata simpangan atau nilai koreksinya sebesar 6,63 yang didapatkan dari rumus. Kemudian dari hasil pembacaan nilai error rata-rata didapatkan sebesar 2,37 \%. Untuk pengujian menggunakan kecap dibandingkan dengan timbangan tipe SF-400, hasil secara keseluruhan diperoleh nilai rata-rata koreksinya sebesar 4,54 dan untuk nilai rata-rata error-nya sebesar 1,76. Sehingga sensor masih bekerja cukup baik karena masih dalam batas toleransi penelitian yaitu sebesar $5 \%$.

Pengujian menggunakan air dan sirup dilakukan untuk melihat proses pencampuran sebagai perumpamaan dari darah dan antikoagulan. Hasil perubahan dapat dilihat ketika proses pencampuran dengan masing-masing kecepatan yang berbeda, ketika diatur kecepatan lambat maka proses pencampuran akan lebih lama dibandingkan dengan pengaturan kecepatan motor yang cepat. Jadi dapat disimpulkan bahwa semakin cepat kecepatan motor yang digunakan akan mempercepat proses pencampuran antara darah dan koagulan.

\section{KESIMPULAN}

Berdasarkan penelitian yang telah dilakukan, dapat disimpulkan bahwa:

a. Pada penelitian ini dapat merancang alat Blood Bag Shaker dilengkapi pemilihan kecepatan motor, dengan kesalahan error kurang dari batas toleransi sebesar $5 \%$.

b. Pada penelitian ini dapat merancang rangkaian minimum sistem mikrokontroler ATMega 328 serta dapat merancang program untuk pemilihan ukuran volume serta pengaturan pemilihan kecepatan motor.

\section{DAFTAR PUSTAKA}

[1] K. Fitryadi, "Pengenalan Jenis Golongan Darah Menggunakan Jaringan Syaraf Tiruan Perceptron," vol. 7, no. 1, 2017.

[2] T. Pribadi, A. L. Indrayanti, and E. V. Yanti, "PENINGKATAN PARTISIPASI MASYARAKAT DALAM KEGIATAN DONOR DARAH DI PALANGKARAYA," $J$. Pengabdi. Al-Ikhlas, vol. 3, no. 1, pp. 50-58, May 2018.

[3] M. Naid, T., Arwie, "Pengaruh Waktu Penyimpanan terhadap Jumlah Eitrrosit Darah Donor," As-Syifaa, vol. 04, no. 01, pp. 112-120, 2012.

[4] R. A. Nugroho, M. Hewan, and J. Biologi, "UJI AKTIVITAS ANTIKOAGULAN EKSTRAK PROPOLIS Trigona laeviceps TERHADAP DARAH MENCIT ( Mus musculus L .)," Pros. Semin. Sains dan Teknol. FMIPA Unmu, no. September, pp. 1-10, 2015.

[5] P. B. Mulyadi, "Clinical Pathology and Majalah Patologi Klinik Indonesia dan Laboratorium Medik," J. Indones., vol. 17, no. 2, pp. 261-265, 2011.

[6] P. Hastari, "Perbedaan Hasil Pemeriksaan Albumin pada Serum yang Segera Dipisah dan Tidak Segera Dipisah dari Bekuan Darah,” J. Chem. Inf. Model., p. 2019, 2019.

[7] W. Arningsih, A. Sukeksi, and B. Santosa, "PENGARUH ANTIKOAGULAN K3DTA DAN HEPARIN VAKUNTAINER TERHADAP JUMLAH TROMBOSIT DENGAN METODE AUTOMATIK," 2014.

[8] S. L. Solichah, M. R. Makruf, and D. Titisari, "Alat Automatic Blood Bag Shaker," 2015.

[9] S. Wardoyo and A. S. Pramudyo, Pengantar Mikrokontroler dan Aplikasi pada Arduino. TEKNOSAINS, 2015.

[10] K. Muhammad, "Aplikasi Accelerometer pada Penstabil Monopod Menggunakan Motor Servo," 2016.

[11] D. Julianto, "Media Pembelajaran Trainer Motor Dc, Brushless, Servo, Dan Stepper Dengan Kendali Mikrokontroler Arduino Uno Pada Mata Pelajaran Teknik Mikroprosesor Di SMK Negeri 2 Depok Yogyakarta," 2017.

[12] M. R. Putra, "Aplikasi Sensor Load Cell Sebagai Pengukur Berat Serpihan Cangkir Plastik Air Mineral Untuk Menonaktifkan Motor Ac Pada Rancang Bangun Mesin Penghancur

Medika Teknika : Jurnal Teknik Elektromedik Indonesia, Vol 01 No. 2, April 2020 50 


\section{Safitri, Iswara, Harjono}

Blood Bag Shaker Dilengkapi Pemilihan Kecepatan Motor

Plastik," p. 2016, 2016.

[13] R. M. Lestari and T. Hamzah, "Blood Bag Mixer Berbasis Mikrokontroller AT89s51," p. 2011, 2011.

[14] C. Agus Sugianto and T. Muhammad Zundi, "Rancang Bangun Aplikasi Donor Darah Berbasis Mobile di PMI Kabupaten Bandung," KOPERTIP J. Ilm. Manaj. Inform. dan Komput., vol. 1, no. 1, pp. 11-18, 2017. 